\title{
Product Market Integration and Wage Formation
}

\author{
Torben M. Andersen \\ University of Aarhus \\ Jan Rose S $\phi$ rensen \\ University of Aarhus
}

\begin{abstract}
This paper analyses the basic labour market inter-dependencies among coun tries with intra-industrial trade and imperfectly competitive product and labour markets. The paper stresses two major channels through which increased integration may affect product markets and therefore in turn labour markets. First, market entry becomes easier and/ or less costly implying that more goods become traded goods. Second, market integration among economi es already open to trade may reduce the explicit or implicit trade costs of selling in foreign markets. It is found that the two channels have different implications for wage formation. (JEL Classifications: F 12, F15, J31, J 51)
\end{abstract}

४ey Words: Trade Costs, Intra-industry Trade, Wage F ormation>

\footnotetext{
* Correspondence Address: Department of Economics, University of Aarhus, EPRU and CEPR. (Tel) 86-42-1609, (Fax) 86-13-6334, (E-mail) tandersen@econ.au.dk. An earlier version of this paper was presented at the workshop "International Trade, Labor M arket, and Integration", Tartu, 1999.

Comments from an anonymous referee are gratefully acknowledged.
}

(C2000 - Center for International Economics, Sejong Institution. All rights reserved. 


\section{Introduction}

Over the last decades we have observed further liberalizations of international trade and accordingly increased international product market integration. In Europe this has been intensified by the "internal market", and the establishment of the "European M onetary Union" is often asserted to strengthen this process further. This is mirrored in an upward trend in international trade in particular for intra-industry trade and trade within regions. While most observers agree that this creates the potential for welfare improvements according to standard arguments of international trade, there is - in particular in Europe - a concern that labour markets are insufficiently flexible to make it possible to reap the full benefits of this process. Accordingly there is a risk that unemployment problems may be intensified, in particular for groups (like unskilled) which in the past have been protected from international competition.

If this is the case, there is an urgent need for labour market reforms in a number of European countries so as to ensure increased flexibility and adaptability in the labour market. On the other hand it is also possible that such flexibility will arise endogenously as agents in the labour market will have to adapt to changes in the market conditions they are facing. That is, labour market inflexibility may fully or partly have been developed under the protection international trade restrictions provided. If so, one should expect product market integration to lead to changes in labour market behaviour including wage determination, contract forms, institutions etc., implying that there is not necessarily a specific need for policy initiatives.

Arguments along this line are based on the factor price equalization theorem according to which free trade and accordingly equalization of relative product prices across countries would imply that relative factor prices also have to be the same across countries. That is, even in the absence of perfect factor mobility free trade will ensure equalization of factor prices. The factor price equalization theorem relies on a number of crucial assumptions of which one is that there is perfect competition in product markets. This assumption is counterfactual for a number of products and factor price equalization does not necessarily follow from free trade. M arket power arises among other things from specialization in production and differentiation 
of products to establish segmented markets. Empirical evidence shows that intra-industry trade is very important and that it has been on the rise. The question of how free trade affects product market conditions and in turn wage determination is therefore not trivial.

Product market conditions do in general influence wage determination as demonstrated by eg Dowrick [1989]. Structural conditions in the product markets allowing for high profit margins tend thus to lead to higher real wages. Accordingly, product market integration and the implied fall in market power for firms may thus induce wage moderation even if labour is inter nationally immobile. The literature has focused on the fact that although free trade does not automatically ensure perfect competition in product markets, it does intensify competition by facilitating the entry of foreign producers on domestic markets, by increasing the set of differentiated goods available for consumers etc. This may in turn affect both the position and the slope of the labour demand function faced by wage setters. The specific implications of this for labour markets have been explored by Driffill and van der Ploeg [1993, 1996], Danthine and Hunt [1995], Huizinga [1993],

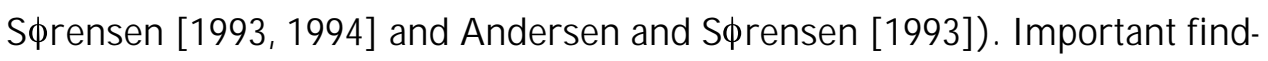
ings include that although wage moderation may be induced, a fall in unemployment does not necessarily follow as this depends on the initial competitive position of the country. M oreover, the relationship between economic performance and the degree of centralization in wage bargaining flattens out, and an incentive for unions to cooperate inter nationally may be created.

The starting point of this paper is the observation that product markets as well as labour markets are imperfectly competitive. We set up a simple theoretical model with intra-industry trade, Cournot competition in goods markets, and with wages determined by trade unions. In this simple model we consider the implications of two dimensions in which product market integration can go. First, we look at the implications of a decrease in trade costs, and secondly we look at the implications of firms getting access to a larger market. We find that a decrease in the trade costs gives rise to an increase in wages, but it does not affect the sensitivity of domestic wages to changes in foreign wages. Contrary to that, the implications of firms getting access to more markets is that the domestic wages become more sensitive to changes in foreign wages. The direction in which wages adjust depends on 
the initial situation.

The paper is organized as follows: Section II develops the model, and section III considers the relation between product market integration and wage formation from a single country perspective, while section IV considers the multi-countr y case. A few concluding remarks are given in section $\mathrm{V}$.

\section{Foreign Trade and Wage Determination}

Consider two countries each producing differentiated goods some of which are traded. In each country there is a representative consumer with a utility function

$$
U=Q_{0}+\sum_{i=1}^{M}\left(Q_{i}-\frac{1}{2} Q_{i}^{2}\right)
$$

where $Q_{0}$ is consumption of a nummeraire good produced in a competitive sector, and $Q_{\mathrm{i}}$ is consumption of the good produced in sector $\mathrm{i}$ which is one of $\mathrm{M}$ imperfectly competitive sectors. For simplicity, we assume that the $\mathrm{M}$ goods produced in imperfectly competitive sectors enter symmetrically in the utility function. We get the following demand functions

$$
\begin{aligned}
& Q_{i}=-p_{i}, \quad i=1, \ldots ., M \\
& Q_{0}=y-\sum_{i=1}^{M}\left(p_{i}-p_{i}^{2}\right)
\end{aligned}
$$

We assume that the parameter values in the model are such that the demand for the nummeraire good is positive. Due to the constant marginal utility from consumption of the nummeraire good, this sector becomes a kind of buffer sector, since there is no income effect in the demand of the other $\mathrm{M}$ goods. By reference to Walras law, we can in the following focus on the $M$ imperfectly competitive sectors.

We will assume that $n$ of the $M$ goods are traded internationally, whereas the rest, $M-n$, are non-traded goods. The goods are ordered such that the $n$ goods with lowest numbers are traded. By using (2), domestic prices on traded goods are given as

$$
p_{i}=a-b\left(q_{i}+q_{i}^{f}\right), \quad i=1, \ldots n
$$


where $a \equiv \beta / \alpha$ and $b \equiv 1 / \alpha$. The supply of domestic firms to the domestic market is denoted $q_{i}$, and the supply of foreign firms to the domestic market is denoted $q_{i}^{f}$.

Domestic prices on non-traded goods are given as

$$
p_{i}=a-b q_{i}, \quad i=n+1, \ldots . M
$$

Similarly, prices on traded and non-traded goods in the foreign country are given as

$$
\begin{aligned}
& \tilde{p}=a-b\left(\tilde{q}_{i}+\tilde{q}_{i}^{f}\right), \quad i=1, \ldots . n \\
& \tilde{p}_{i}=a-b \tilde{q}_{i}^{f}, \quad i=n+1, \ldots ., M
\end{aligned}
$$

where a " $\sim$ " indicates that it is a variable related to the foreign market.

For simplicity, we assume that there is only one firm in each country producing each good. The profit of a domestic firm producing a non-traded good is given as

$$
{ }_{i}=p_{i} q_{i}-w l_{i}, \quad i=n+1, \ldots, M
$$

where $w$ is the wage rate in the imperfectly competitive sectors. The profit of a domestic firm producing a traded good becomes

$$
{ }_{i}=p_{i} q_{i}+\tilde{p}_{i} \tilde{q}_{i}-w l_{i}-t_{i} \tilde{q}_{i}, \quad i=1, \ldots ., n
$$

where $t$ is a trade cost due to transportation and other transactions costs related to foreign trade. We have similar profit expressions for foreign firms.

We assume that firms operate with a simple linear production function, i.e. for a firm producing tradeables

$$
q_{i}+\tilde{q}_{i}=l_{i}, \quad i=1, \ldots . n
$$

and for a firm producing non-tradeables

$$
q_{i}=l_{i}, \quad i=n+1, \ldots . M
$$

Profit maximization by a domestic firm producing non-traded goods implies that production becomes

$$
q_{i}=\frac{a-w /}{2 b} \quad i=n+1, \ldots, M
$$

By maximizing profits in domestic and foreign firms producing traded 
goods, the Cournot-N ash equilibrium implies that the supply of goods to the domestic and foreign markets by domestic firms become, respectively

$$
\begin{aligned}
& q_{i}=\frac{a+\tilde{w} /+t-2 w /}{3 b}, \quad i=1, \ldots, n \\
& \tilde{q}_{i}=\frac{a+\tilde{w} /-2 w /-2 t}{3 b}, \quad i=1, \ldots . n
\end{aligned}
$$

Domestic supply in both markets is decreasing in the domestic and increasing in the foreign wage, i.e. an improvement of competitiveness increases production and employment. M oreover, we see that trade costs give rise to an increase in domestic supply in the domestic market but a decrease in the foreign market. However, the decrease in the foreign market is larger than the increase in the domestic market implying that an increase in trade costs causes a decrease in production and employment.

Total domestic employment in the imperfectly competitive sectors is given as

$$
\begin{aligned}
& L=\frac{\sum_{i=1}^{n}\left(q_{i}+\tilde{q}_{i}\right)+\sum_{i=n+1}^{M} q_{i}}{3 b} \\
& =n \frac{2 a+2 \tilde{w} /-4 w /-t}{3 b}+(M) \frac{a-w /}{2 b}
\end{aligned}
$$

Higher domestic wages reduce employment, and higher foreign wages increase employment. A change in labour productivity has an ambiguous effect on employment. On the one hand, an increase in productivity tends to decrease labour costs, but on the other hand less labour is needed for a given production. A decrease in trade costs tends to increase employment, but this is the net result of two counteracting effects. A reduction in trade costs makes it more profitable to export which tends to increase employment, but it also makes it more profitable for foreign firms to export to the domestic market which tends to decrease domestic employment. However, in the present set-up the former dominates and the net effect is an increase in employment. Finally, an increase in the number of traded goods tends to increase employment. This is so because domestic and foreign firms compete in the markets for traded goods. Hence, the degree of competition tends to increase when more goods become traded, and more competition 
tends to give rise to a higher supply and in turn a higher employment. This is at least the case if the competitiveness of the domestic industry is not too bad. If domestic wages are much higher than foreign wages, employment may decrease as a result of an increase in the number of traded goods.

Wages are assumed to be set in negotiations between workers organized in unions and employers organized in employers federations. The negotiations take place under a right to manage structure, that is, firms determine employment so as to maximize profits given the negotiated wages. Hence, employment is for any wage determined by (15). As is well known from the literature on wage bargaining the outcome depends on the rent to be shared, the bargaining power and the available outside options.

A domestic trade union organizes the workers employed in the imperfectly competitive sector. This trade union is assumed to maximize the expected income of a representative member ${ }^{1}$ which is equivalent to maximising

$$
\Omega=L(w-v)
$$

where $v$ is the reservation wage or outside option to workers (can be interpreted as the leisure value, unemployment benefits or wage in alternative employment). In the present context it can also be interpreted as the income of a worker who does not become employed in one of the $M$ imperfectly competitive sectors but instead in the competitive nummeraire sector.

For simplicity, we assume that the trade union determines the wage rate unilaterally (monopoly union). Hence, by maximizing (16) with respect to $\mathrm{w}$, and using (15), we find that the optimal wage set by the domestic trade union becomes

$$
w=\frac{1}{2} v+a_{1}+a_{2} \tilde{w}
$$

1. It is assumed that the union disregards the consequences wage changes may have for prices, which is not consistent with the assumption that the union represents all workers in the imperfectly competitive part of the economy. We see this as a modelling simplification allowing us to circumvent the problems of having to model separate unions for each sector/ firm implying that price changes on goods produced in sectors where members from this specific trade union work have no significant influence on the utility of the trade union members. 
where ${ }^{2}$

$$
=\frac{(n+3 M) a-2 n t}{10 n+6 M}>0, \quad o<{ }_{2}=\frac{2 n}{3 M+5 n}<1
$$

This equation has the interpretation of a reaction function giving the optimal wage for the domestic union given wages set by foreign unions. The functional form and the sign of the derivatives follow from the specific model, but the qualitative properties generalize to far less specific models. Basically, wages are influenced by three types of concerns. Firstly, the higher the alternative income, the higher the wage rate. Secondly, the higher the labour productivity, the higher the wage rate. Finally, the higher the foreign wage rate, the higher the wage. This captures that domestic and foreign wages are strategic complements, i.e. wage reaction functions are positively sloped ${ }^{3}$ as indicated in figure 1 . In other words, a concern for competitiveness implies that foreign wages have to be taken into account when domestic wages are determined, and higher foreign wages implies that domestic wages can be higher without losing competitiveness.

\section{Integration and Wage Formation}

The interesting question is how the incentives in wage formation are affected by increased product market integration. Integration may lead to an increase in the relative number of tradeable goods $(n)$ or a reduction in marginal trade costs $(\mathrm{t})$.

Considering first an increase in the number of goods traded internationally, we find

$$
\frac{1}{n}<0, \frac{2}{n}>0
$$

Hence, the reaction function will be shifted downwards, but the slope will increase implying that the domestic wage becomes more sensitive to changes in the foreign wage rate, cf. figure 1.

2. It must be the case that $t<a$, otherwise the highest possible price on the good (i.e. a) would be lower than the unit transport cost on the good.

3. Domestic and foreign trade unions are in a kind of Bertrand game. 


\section{Figure 1.}

\section{An Increase in the Relative Number of Tradeable Goods}

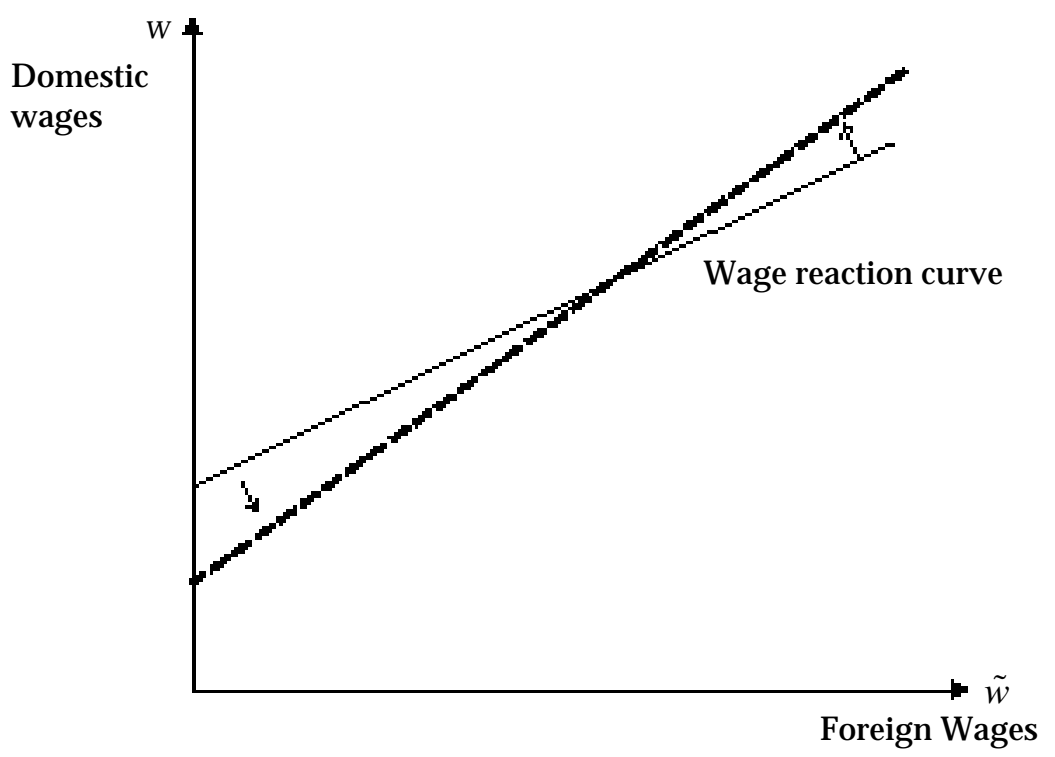

The increase in the slope implies that domestic wages become more sensitive to foreign wages. It is an implication that if integration takes place for a low value of foreign wages (i.e. the initial competitive situation of the domestic economy is non-favourable) then it will induce a downward pressure on wages. Oppositely if foreign wages are high (i.e. the initial competitive situation of the domestic economy is favourable) domestic wages tend to increase as a consequence of enhanced possibilities for market entry. This suggests that integration has the largest benefits for countries with an initial competitive advantage.

If integration of product markets implies a decrease in the trade cost ( $t$ ) we see that the reaction function of the domestic trade union shifts upwards since

$$
\frac{w}{t}=\frac{1}{t}<0
$$

This is so because it becomes more profitable to export. This in turn gives rise to an increase in labour demand, and the trade union responds by 
increasing the wage rate, cf figure 2 .

The often made assertion that integration will eliminate market power in labour markets and thus any domestic influence on wage formation corresponds in the figures to the situation where the reaction curve equals the $45^{\circ}-$ line, that is, the domestic unions are forced to set wages equal to foreign wages. Even in the extreme case where trade costs are zero and all goods are tradeables this situation does not prevail as long as firms still have some market power in the product market. That is, given some product market power to firms there is a rent for unions to bargain over and this implies a non-trivial choice between wages and employment. Although product market integration may weaken the power of wage setters it is not realistic that this process will proceed to the point where wages are pushed to the reservation wage. $N$ ote that even if all the differentiated goods are traded internationally $(n=M)$, we have that

$$
\frac{w}{\tilde{w}}={ }_{2}<1
$$

that is, the domestic labour market is not simply reduced to a follower position.

Figure 2.

\section{Lower Trade Costs}

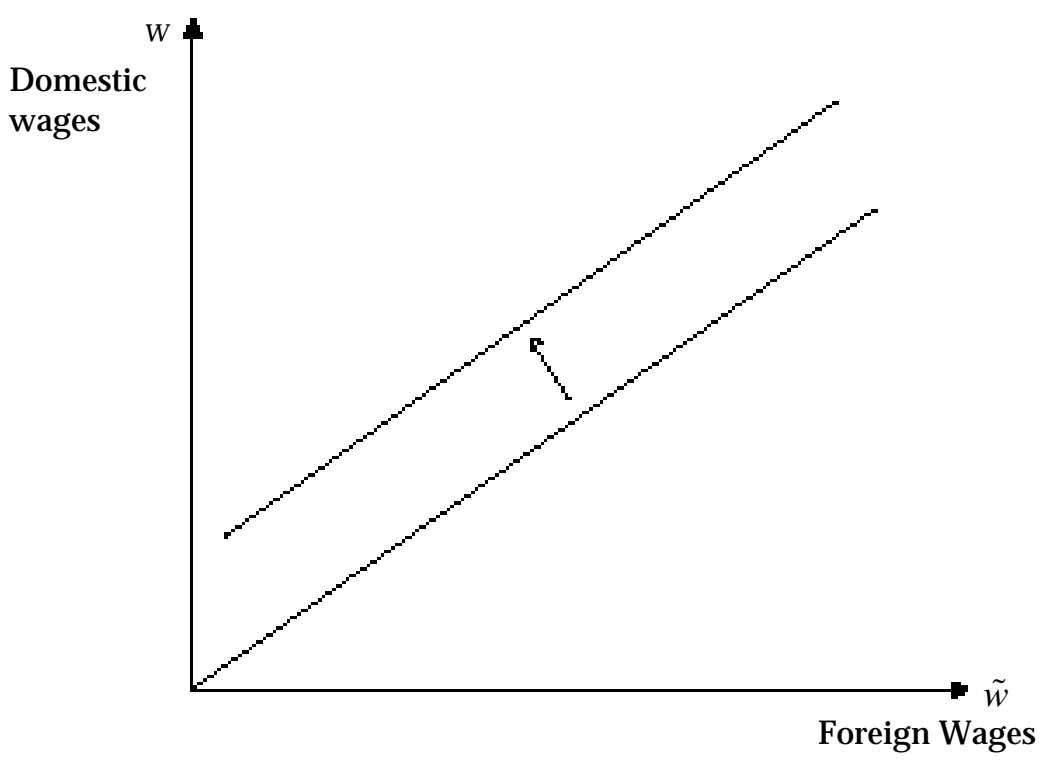




\section{General Equilibrium Effects}

Although it is not plausible that all countries and thus labour markets are identical, it can be a useful theoretical exercise to investigate the symmetric equilibrium arising when all countries are identical. This is illustrated in figure 3 displaying the symmetric Bertrand-N ash equilibrium to the international model of wage setting presented here.

The symmetric Bertrand-Nash equilibrium in wages can be found by inserting $w=\tilde{w}$ into (17), and we find that

$$
w=\tilde{w}=\frac{1 / 2+{ }_{1}}{1-{ }_{2}}
$$

Notice that the symmetric equilibrium by construction has factor price equalization in the sense that wages are the same in all countries. Although an obvious implication of the imposed symmetry condition, it highlights that factor price equalization does not necessarily imply that market power is dissipated in the labour market. Actually, in the situation depicted in figure 3 wages are above the reservation wages of workers which in the present setting would be the competitive wage level. The point is that for fairly similar countries, wages can be roughly similar, without this implying that market power has been eliminated.

Consider now the effects of international integration. An increase in the number of traded goods has the following effects

$$
\frac{w}{n}=\frac{\frac{1}{n}\left(1-{ }_{2}\right)+\frac{2}{n}\left(\frac{1}{2} v+{ }_{1}\right)}{\left(1-{ }_{2}\right)^{2}}
$$

Since $\mathrm{w}<\gamma$ and $\left|\frac{1}{n}\right|>\left|\frac{2}{n}\right|$ it follows that

$$
\frac{w}{n}<0
$$

Hence, if product market integration gives rise to an increase in the number of goods which are traded, we should expect equilibrium wages to decrease. This is so because there is an increase in the degree of competition in goods markets which spill overs at the labour market.

It is easily seen that $w$ is decreasing in $t$. If integration of product markets give rise to a decrease in trade costs, we should expect equilibrium wages 
Figure 3.

\section{Symmetric Bertrand-Nash Equilibrium}

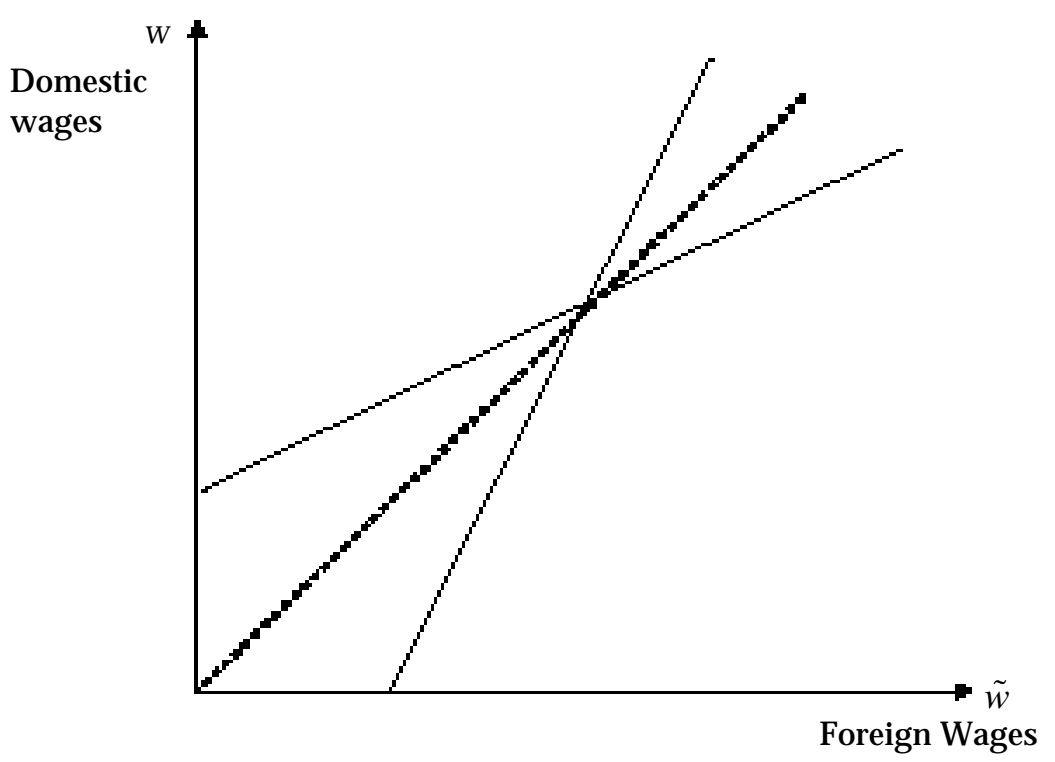

to increase.

\section{Concluding Remarks}

The present paper has addressed how product market integration may affect wage formation when both product and labour markets are imperfectly competitive. It was found that integration may work on two dimensions (trade costs and number of traded goods) with different implications for wage formation. Hence, it cannot simply be concluded that intensified product market competition induced by integration of product markets leads to wage moderations.

\section{References}

Andersen, T.M ., and J.R. Sprensen [1993], "Will Product M arket Integration Lower Unemployment," in J an Fagerberg and Lars Lundberg (eds.): European E conomic Integration: A N ordic Perspective, Avebury. 
Danthine, J.-P. and J. Hunt [1994], "Wage Bargaining Structure, Employment and Economic Integration," E conomic J ournal 104; pp. 528-41.

Dowrick, S. [1989], "U nion-Oligopoly Bargaining," E conomic Journal 99; pp. 1123-42.

Driffill, J . and R.van der Ploeg [1993], "M onopoly U nions and the Liberalisation of International Trade," E conomic Journal 103; pp. 379-85.

Driffill, J. and R. van der Ploeg [1995], "Trade Liberalization with Imperfect Competition in Goods and Labor M arkets," Scandinavian Journal of Economics 97; pp. 223-243.

Huzinga, H . [1993], "International M arket Integration and U nion Wage Bargaining," Scandinavian Journal of E conomics 95; pp. 249-55.

Oswald, A.J . [1985], "The Economic Theory of Trade Unions: An Introductory Survey," Scandinavian Journal of Economics 87; pp. 160-93.

Sprensen, J.R. [1994], "Integration of Product M arkets when Labour M arkets are Unionized," Recherches Economique de Louvain 59; pp. 485502.

Sprensen, J.R. [1994], "M arket Integration and Imperfect Competition in Labour and Product M arkets," O pen Economies Review 5; pp. 115-130. 